\title{
SISTEM PENDUKUNG KEPUTUSAN PEMBERIAN BANTUAN PROGRAM KELUARGA HARAPAN (PKH) PADA ORANG MISKIN DI KOTA TERNATE MENGGUNAKAN METODE AHP
}

\author{
Akbar Riodano Laisouw ${ }^{1}$, Salkin Lutfi ${ }^{2}$, Firman Tempola ${ }^{3}$ \\ Program Studi Teknik Informatika, Fakultas Teknik, Universitas Khairun \\ Jl. Jati Metro, Kota Ternate Selatan \\ E-mail: riodanoakbar@gmail.com¹, salkin.lutfi@gmail.com², firman.tempola@unkhair.ac.id. ${ }^{3}$
}

\begin{abstract}
In the provision of social assistance PKH (family hope program) in the Social Service Office of the City of Ternate is still not optimal, because at the time of the selection of recipients of assistance there was no supporting system so that during the selection process still using estimates and the absence of calculations during the selection of beneficiaries. So that few or many people sometimes protest because people who are supposed to get help but they don't get the assistance, and vice versa. This study aims to make a decision support system in the provision of social assistance for family planning programs using the Analytic Hierarchy Process method. The criteria used are 7 criteria, namely Disability, Elderly, Pregnant / postpartum, Children under 6 years of age, Elementary School Children, Middle School and High School Children. The Analytic Hierarchy Process method is a method of settlement using a calculation of pairwise comparison matrices, where each criterion is weighted and a pairwise comparison matrix is calculated. The results of this study are in the form of a decision support system application for PKH assistance in the city of Ternate based on the web which can provide recommendations to the Social Service Office of the City of Ternate as a consideration for decision making in PKH assistance.
\end{abstract}

Keywords: Decision Support Systems, PKH, Analytic Hierarchy Process, Web.

Abstrak - Dalam pemberian bantuan sosial PKH (program keluarga harapan) pada Dinas Sosial Kota Ternate masih belum optimal, karena pada saat pemilihan penerima bantuan belum ada sistem yang mendukung sehingga pada saat proses pemilihan masih menggunakan perkiraan saja dan belum adanya perhitungan pada saat pemilihan penerima bantuan tersebut. Sehingga sedikit atau banyaknya warga terkadang protes karena warga yang seharusnya mendapatkan bantuan tetapi mereka tidak mendapatkan bantuan tersebut, begitupun sebaliknya. Penelitian ini bertujuan untuk membuat sebuah sistem pendukung keputusan dalam pemberian bantuan sosial program keluarga harapan dengan menggunakan metode Analytic Hierarchy Process. Kriteria yang digunakan ada 7 kriteria yaitu Disabilitas, Lanjut usia, Ibu hamil/nifas, Anak usia di bawah 6 tahun, Anak SD, Anak SMP dan Anak SMA. Metode Analytic Hierarchy Process adalah metode penyelesaian dengan menggunakan perhitungan matriks pairwise comparison (perbandingan berpasangan), dimana setiap kriteria dibobotkan dan dilakukan perhitungan matriks perbandingan berpasangan. Hasil dari penelitian ini berupa aplikasi sistem pendukung keputusan pemberian bantuan PKH di Kota Ternate berbasis web yang dapat memberikan rekomendasi kepada pihak Dinas Sosial Kota Ternate sebagai bahan pertimbangan untuk pengambilan keputusan dalam pemberian bantuan PKH.

Kata Kunci: Sistem Pendukung Keputusan, PKH, Analitycal Hierrarchy Process, Web. 


\section{PENDAHULUAN}

\subsection{Latar Belakang}

Kota Ternate merupakan ibu kota dari Pemerintah Daerah yang berada di Provinsi Maluku Utara, Ternate pertama menjadi Kota otonom sejak 4 Oktober 1999, Tepatnya sampai dengan 4 Agustus 2010, setelah 11 tahun masa transisi dan persiapan infrastruktur, ibukota Provinsi Maluku Utara dipindahkan ke Kota Sofifi yang terletak di Pulau Halmahera yang merupakan pulau terbesarnya. Kota Ternate terletak di pulau Ternate dengan luas wilayah $111,39 \mathrm{~km} 2$ dan jumlah jiwa 207.789.(BPS, 2015).

Tercatat jumlah penduduk miskin di Provinsi Maluku Utara pada 2015 bertambah 2,2 ribu orang dari tahun lalu sebanyak 84,64 ribu orang, kenaikan ini terjadi lantaran pengaruh kebutuhan ekonomi di Maluku Utara yang terus meningkat. Persentase penduduk miskin di Maluku Utara pada maret 2017 mencapai 6,35 persen $(76,47$ ribu orang) dibandingkan dengan penduduk miskin pada september 2016 yang sebesar 6,41 persen $(76,40$ ribu orang). Peningkatan angka kemiskinan di Maluku Utara bisa menjadi masalah baru dalam proses pembangunan.(BPS, 2015) [1].

Dengan adanya sistem pendukung keputusan diharapkan dapat menekan angka kemiskinan yang terus menignkat di kota ternate, karena pada dinas sosial kota ternate belum mempunyai sistem yang membantu dalam pemberian bantuan sosial salah satunya adalah bantuan program keluarga harapan (PKH).

Secara umum permasalahan yang terjadi pada pemberian PKH (program keluarga harapan) pada Dinas Sosial Kota Ternate masih belum optimal, karena pada saat pemilihan penerima bantuan belum ada sistem yang mendukung sehingga pada saat proses pemilihan masih menggunakan perkiraan saja dan belum adanya perhitungan pada saat pemilihan penerima bantuan tersebut. Sehingga sedikit atau banyaknya warga terkadang protes karena warga yang seharusnya mendapatkan bantuan tetapi mereka tidak mendapatkan bantuan tersebut, begitupun sebaliknya.

Dengan adanya SPK (sistem pendukung keputusan) bertujuan untuk memberikan rekomendasi dalam pengambilan keputusan pemberian bantuan PKH dengan lebih cepat dan akurat. Dengan adanya kemampuan sistem pendukung keputusan dalam pengambilan keputusan sesuai dengan metode yang dirancang diharapkan dapat sedikit membantu dalam pengambilan keputusan pemberian bantuan $\mathrm{PKH}$ pada Dinas Sosial Kota Ternate, dalam sistem yang dirancang ini menggunakan metode AHP (Analytic Hierarchy Process), Peralatan utama AHP adalah memiliki sebuah hirarki fungsional dengan input utamanya persepsi manusia. Dengan hirarki, suatu masalah kompleks dan tidak terstruktur dipecahkan ke dalam kelomok-kelompoknya dan diatur menjadi suatu bentuk hirarki.
Dengan pemanfaatan SPK (Sistem Pendukung Keputusan) dalam pengambilan keputusan pemberian bantuan PKH (Program Keluarga Harapan) di Kota Ternate diharapkan dapat membantu Dinas Sosial Kota Ternate dalam mengambil keputusan untuk pemberian bantuan kepada orang miskin di Kota ternate agar lebih tepat dan terarah. Berdasarkan pemikiran tersebut penulis mencoba untuk membuat "SISTEM PENDUKUNG KEPUTUSAN PEMBERIAN BANTUAN PROGRAM KELUARGA HARAPAN (PKH) PADA ORANG MISKIN DI KOTA TERNATE”.

\section{TINJAUAN PUSTAKA}

\subsection{Sistem Pendukung Keputusan}

Definisi Sistem Pendukung Keputusan (Adisty, 2013), Konsep Sistem Pendukung Keputusan (SPK)/Decision Support System (DSS), merupakan sistem informasi interaktif yang menyediakan informasi, pemodelan, dan pemanipulasian data. Sistem itu digunakan untuk membantu pengambilan keputusan dalam situasi yang semiterstruktur dan situasi yang tidak terstruktur, dimana tak seorang pun tau secara pasti bagaimana keputusan seharusnya dibuat [2].

\subsection{Metode (AHP) Analitical Hierrarchy Process}

AHP merupakan suatu model pendukung keputusan yang dikembangkan AHP merupakan suatu model pendukung keputusan yang dikembangkan oleh Thomas L. Saaty. Model pendukung keputusan ini akan menguraikan masalah multi faktor atau multi kriteria yang kompleks menjadi suatu hirarki.

Hirarki didefinisikan sebagai suatu representasi dari sebuah permasalahan yang kompleks dalam suatu struktur multi level dimana level pertama adalah tujuan, yang diikuti level faktor, kriteria, sub kriteria, dan seterusnya ke bawah hingga level terakhir dari alternatif. Dengan hirarki, suatu masalah yang kompleks dapat diuraikan ke dalam kelompokkelompoknya yang kemudian diatur menjadi suatu bentuk hirarki sehingga permasalahan akan tampak lebih terstruktur dan sistematis Menurut (Rifan Syaiful, 2011). [3].

Dalam proses perhitungan matriks perbandingan berpasangan untuk kriteria yang dilakukan dan pembobotan dalam melakukan matiks perbandingan berpasangan untuk skala penilaian tingkat kepentignannya ditentukan dan disesuaikan dengan skala penilaian perbandingan berpasangan, seperti yang dapat dilihat pada tabel 2.1 skala penilaian perbandingan berpasangan .

Tabel 2.1 Skala Penilaian.

\begin{tabular}{|c|l|}
\hline $\begin{array}{c}\text { Intensitas } \\
\text { Kepentingan }\end{array}$ & \multicolumn{1}{|c|}{ Keterangan } \\
\hline 1 & Kedua elemen sama penting \\
\hline 3 & $\begin{array}{l}\text { Elemen yang satu sedikit } \\
\text { lebih penting daripada } \\
\text { elemen yang lainnya }\end{array}$ \\
\hline
\end{tabular}




\begin{tabular}{|c|l|}
\hline 5 & $\begin{array}{l}\text { Elemen yang satu lebih } \\
\text { penting dari pada elemen } \\
\text { lainnya }\end{array}$ \\
\hline 7 & $\begin{array}{l}\text { Satu elemen jelas lebih } \\
\text { mutlak penting daripada } \\
\text { elemen lainnya }\end{array}$ \\
\hline 9 & $\begin{array}{l}\text { Satu elemen mutlak penting } \\
\text { daripada elemen lainnya }\end{array}$ \\
\hline Kebalikan & $\begin{array}{l}\text { Nilai-nilai antara dua nilai } \\
\text { pertimbangan yang } \\
\text { berdekatan }\end{array}$ \\
\hline $\begin{array}{l}\text { Jika aktivitas i mendapat } \\
\text { satu angka dibandingkan } \\
\text { dengann aktivitas j, maka j } \\
\text { memiliki nilai kebalikannya } \\
\text { dibandingkan dengann i. }\end{array}$ \\
\hline
\end{tabular}

Penilaian dalam membandingkan antara satu kriteria dengan kriteria yang lain adalah bebas satu sama lain, dan hal ini dapat mengarah pada ketidak konsistensian. indeks konsistensi dari matrik ber ordo $\mathrm{n}$ dapat diperoleh dengan rumus :

$\mathrm{CI}=(\lambda$ maks-n $) /(\mathrm{n}-1)$

Dimana :

$\mathrm{CI}=$ Indeks Konsistensi (Consistency Index)

$\lambda$ maks $=$ Nilai eigen terbesar dari matrik berordo $n$

Nilai eigen terbesar didapat dengan menjumlahkan hasil perkalian jumlah baris dengan eigen vector. Batas ketidak konsistensian diukur dengan menggunakan rasio konsistensi (CR), yakni perbandingan indeks konsistensi (CI) dengan nilai pembangkit random (RI). Nilai ini bergantung pada ordo matriks n, Berikut daftar nilai indeks random (RI) yang dapat dilihat pada tabel 2.2 daftar indeks random $(\mathrm{RI})$.

Tabel 2.2 Daftar Indeks Random (RI)

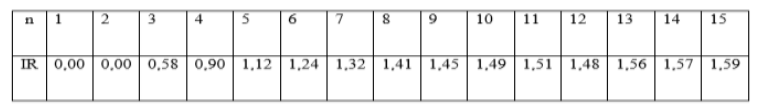

Rasio konsistensi dapat dirumuskan :

$\mathrm{CR}=\mathrm{CI} / \mathrm{RI}$.

Bila nilai CR lebih kecil dari 10\%, ketidak konsistensian pendapat masih dianggap dapat diterima (Sri Kusumadewi dkk, 2006).[4]

2.3. Normalisasi

Normalisasi adalah proses pengskalaan nilai atribut dari data sehingga bisa jatuh pada range tententu. Pada proses normalisasi dilakukan dengan metode Min-Max, yaitu metode normalisasi dengan melakukan transformasi linier terhadap data asli, berikut persamaan pada metode Min-Max:

nilai normalisasi $=\frac{X a w a l-X \min }{X \max -X \min }$ .1

Keterangan:

Xawal $=$ nilai awal

$\mathrm{Xmax}=$ nilai maksimal atau nilai terbesar

Xmin $=$ nilai minimal atau nilai terkecil [5].

2.4. Metode Pengembangan Perangkat Lunak

Prorotype

Metode pengembangan sistem yang digunakan yaitu dengan metode prototyping. Serangkaian sasaran umum bagi perangkat lunak tidak mengidentifikasi kebutuhan input, pemrosesan, ataupun output detail. Pada kasus yang lain, pengembang mungkin tidak memiliki kepastian terhadap efisiensi algoritma, kemapuan penyesuaian dari sistem operasi, atau bentuk-bentuk yang harus dilakukan oleh interaksi manusia dan mesin.

Kesalah pahaman antara user dan analis mengakibatkan perubahan yang berarti atau sistem tidak akan pernah sempurna dalam pelaksanaannya atau sekaligus ditolak. prototype dapat memecahkan masalah ini untuk tipe-tipe tertentu dalam sistem.

Dalam situasi seperti ini salah satu model yang cocok digunakan adalah model Prototyping (Prototyping paradigm) (Atikah Arma, 2013) [6].

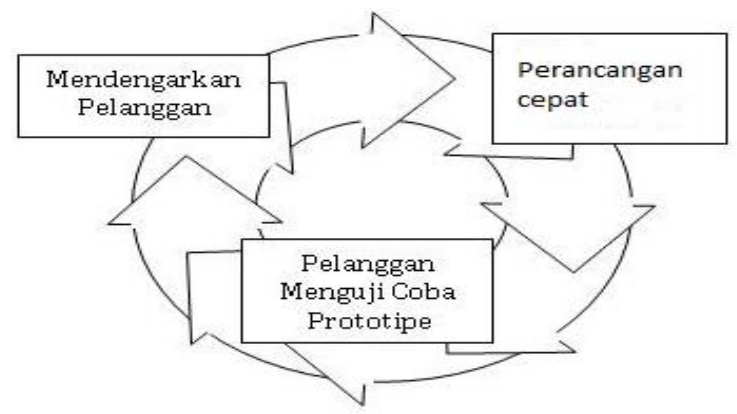

Gambar 1 Metode Pengembangan Prototype.

Prototyping melewati tiga proses, yaitu pengumpulan kebutuhan, perancangan, dan evaluasi Prototyping. Proses-proses tersebut dapat dijelaskan sebagai berikut:

1. Pengumpulan kebutuhan: developer dan pelanggan bertemu dan menentukan tujuan umum, kebutuhan yang diketahui dan gambaran bagian-bagian yang akan dibutuhkan berikutnya. Detail kebutuhan mungkin tidak dibicarakan disini, pada awal pengumpulan kebutuhan.

2. Perancangan: perancangan dilakukan cepat dan rancangan mewakili semua aspek software yang diketahui, dan rancangan ini menjadi dasar pembuatan prototyping.

3. Uji coba prototyping: pelanggan mengevaluasi prototyping yang dibuat dan digunakan untuk memperjelas kebutuhan software. Perulangan ketiga proses ini terus berlangsung hingga semua kebutuhan terpenuhi. Prototyping dibuat untuk memuaskan kebutuhan pelanggan dan untuk memahami kebutuhan pelanggan lebih baik.

\subsection{Program Keluarga Harapan}

Program Keluarga Harapan (PKH) adalah program pemberian bantuan sosial bersyarat kepada keluarga miskin (KM) yang ditetapkan sebagai keluarga penerima manfaat PKH. Dalam istilah internasional dikenal dengan Conditional Cash Transfers (CCT) (DINSOS Kota Ternate, 2017) [7]. 


\section{Metode Penelitian}

\subsection{Analisis Sistem}

Sistem yang akan dibangun pada penelitian ini secara umum merupakan sistem yang di gunakan untuk sedikit membantu dinas sosial dalam pengambilan keputusan pemilihan penerima bantuan sosial Program Keluarga Harapan (PKH) di kota ternate. Sistem ini membantu memberikan rekomendasi pemilihan alternatif yang layak menerima bantuan sosial tersebut sesuai dengan kriteria - kriteria yang sudah ditetapkan.

Data alternatif diperoleh dari hasil survey dan wawancara langsung kepada calon peserta atau masyarakat miskin di kota ternate. Data yang di peroleh akan di tentukan nilai tiap kriteria dan hasilnya akan digunakan pada perhitungan AHP . Dengan metode ini akan di hasilkan nilai berupa alternatif pilihan yang akan di rekomendasikan sistem kepada pengguna sistem.

3.2. Analisis AHP Program Keluarga Harapan

Dalam pemberian bantuan PKH pendamping melakukan validasi dan merekap data kriteria yang layak mendapatkan bantuan tersebut secara manual dan belum ada sistem yang mendukung dalam pembentukan hirarki dan prioritas dalam pemberian bantuan tersebut.

\subsection{Metode Pengembangan Perangkat Lunak}

Metode pengembangan sistem yang digunakan adalah Prototype, Langkah pengembangan perangkat lunak SPK PKH dapat dilihat pada gambar 2 pengembangan perangkat lunak menggunakan metode prototype.

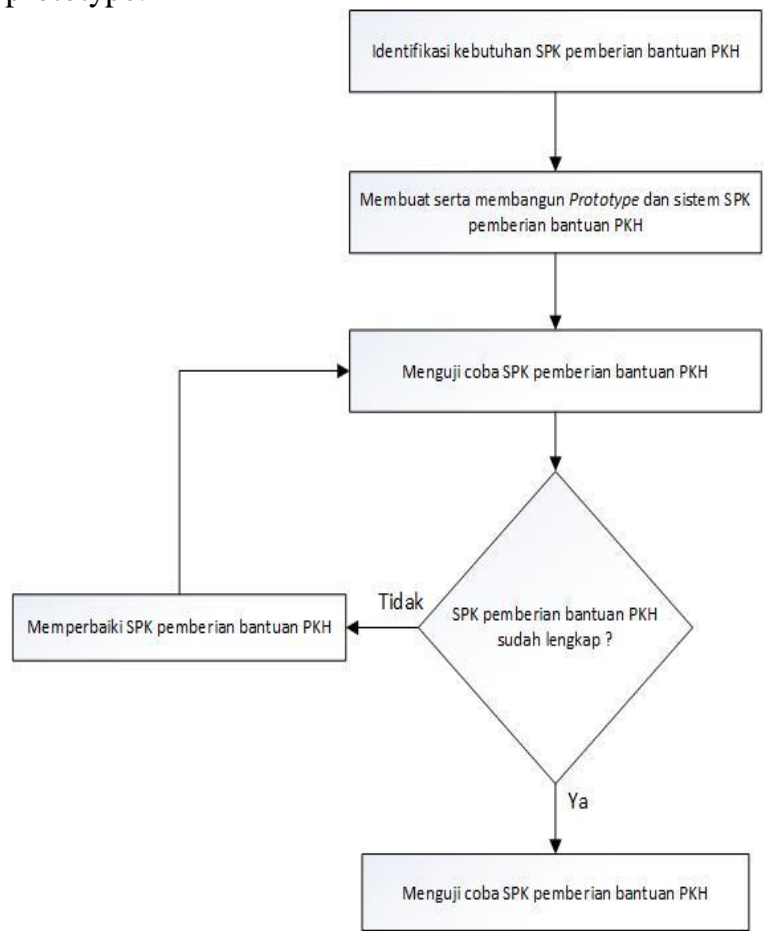

Gambar 2. Pengembangan Perangkat Lunak Sistem Pendukung Keputusan PKH
Deskripsi Pengembangan Sistem:

1. Mengidentifikasi kebutuhan-kebutuhan dalam hal ini kebutuhan dalam SPK Pemberian Bantuan PKH.

2. Membangun Prototype SPK Pemberian Bantuan PKH berdasarkan kebutuhan.

3. Setelah membuat prototype dari sistem kemudian membangun dan menggunakan SPK Pemberian Bantuan PKH menggunakan Bahasa Pemograman PHP dan HTML.

4. Setelah itu, lanjut ke tahap pengujian dengan melibatkan admin dan user.

5. Jika dalam tahapan pengujian ditemukan SPK Pemberian Bantuan PKH belum lengkap maka dilakukan perbaikan dengan meningkatkan sistem berdasarkan kebutuhan yang baru.

6. Apabila SPK Pemberian Bantuan PKH telah lengkap maka selesai. Apabila tidak lengkap maka kembali memperbaiki sistem tersebut.

\section{HASIL DAN PEMBAHASAN}

\subsection{Use Case Diagram}

Berikut ini adalah use case diagram untuk sistem pendukung keputusan pemberian bantuan PKH untuk orang miskin di Kota Ternate yang terbagi dalam 2 diagram yaitu use case diagram admin dan use case diagram pendamping. Dapat dilihat pada gambar 3 Use case diagram admin dan gambar 4 Use case diagram pendamping.

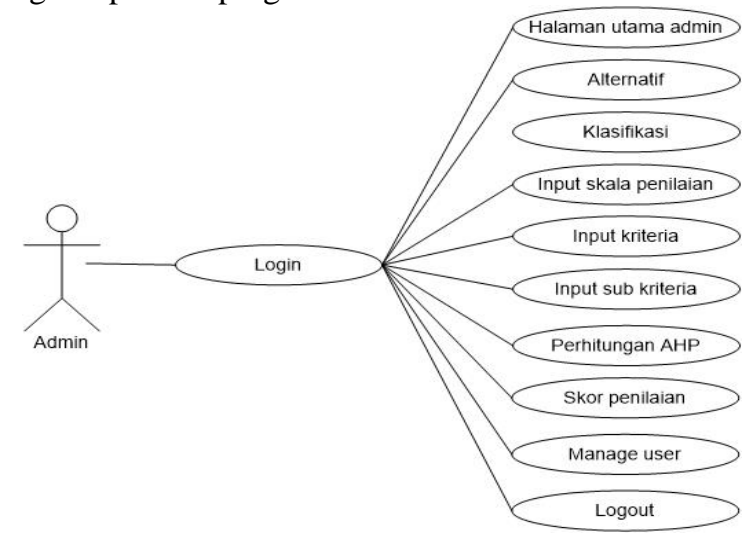

Gambar 3 Use Case Admin

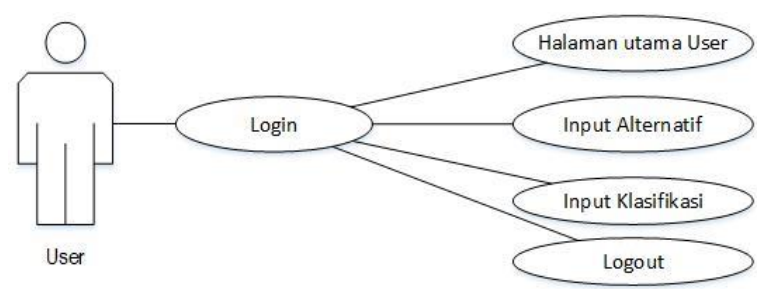

Gambar 4 Use Case Diagram Pendamping

\subsection{Perancangan Database}

Perancangan Database merupakan proses untuk menentukan isi dan pengaturan data yang dibutuhkan untuk mendukung berbagai rancangan sistem. Perancangan database menggunakan ERD (Entity 
Relationship Diagram). Berikut ERD dari sistem yang dibangun dapat dilihat pada gambar 5 .

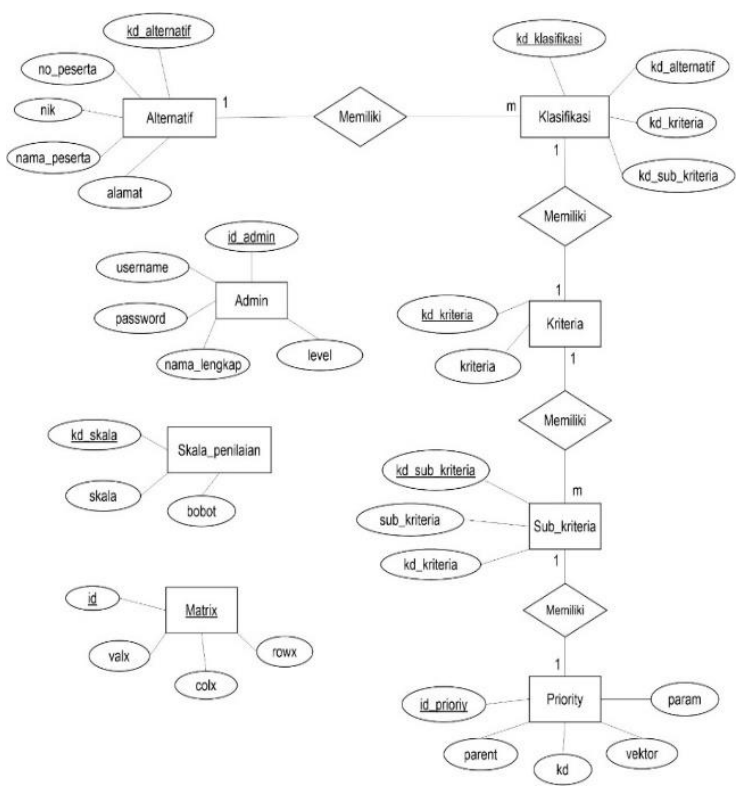

Gambar 5 ERD SPK Pemberian Bantuan PKH

Deskripsi sistem :

1. Admin \{id_admin, username, password, nama_lengkap, level $\}$, Skala_penilaian \{kd_skala, skala, bobot\}, Matrix \{id, valx, colx, rowx \}, Alternatif $\{$ kd_alternatif, no_peserta, nik, nama_peserta, alamat $\}, \quad$ Klasifikasi $\{$ kd_klasifikasi, kd_alternatif, kd_kriteria, kd_sub_kriteria $\}$, Kriteria $\left\{k d \_k r i t e r i a, ~ k r i t e r i a\right\}$, Sub_kriteria \{kd_sub_kriteria, kd_kriteria, sub_kriteria\}, Priority \{id_priority, parent, kd, vektor, param\}

2. Terdapat enam relasi yaitu "relasi memiliki" yang menghubungkan entitas Alternatif dan Klasifikasi, Sub_kriteria dan Klasifikasi, Kriteria dan Klasifikasi, Kriteria dan Sub_kriteria, Kriteria dan Priority, dan Sub_kriteria dan Priority.

4.3. Implementasi Sistem Admin

Berdasarkan perancangan sistem pada diagram activity yang telah diuaraikan, selanjutnya di implementasikan perancangan tersebut menjadi sebuah sistem yang sesuai dengan perancangan interface-nya.

1. Halaman login

Untuk Dapat mengakses menu utama, admin harus login untuk memasukan username dan password yang valid.

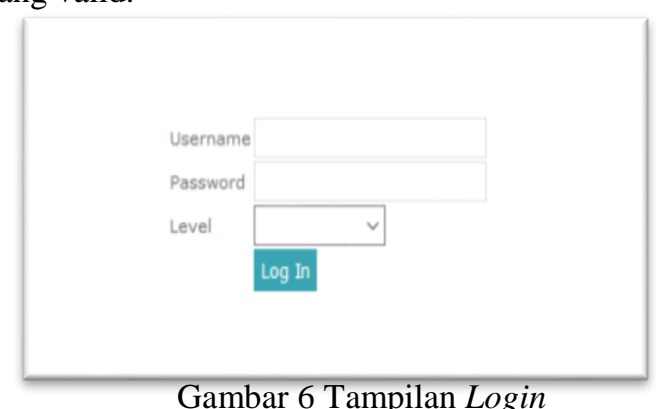

2. Halaman utama admin

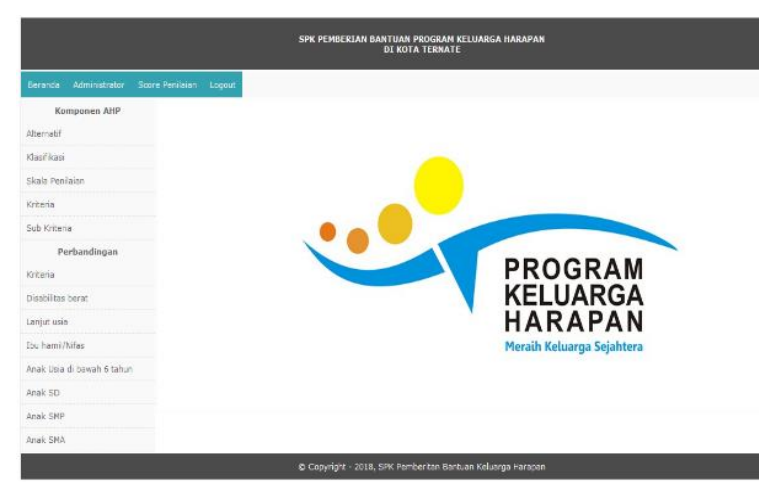

Gambar 7 Halaman utama

3. Halaman kriteria

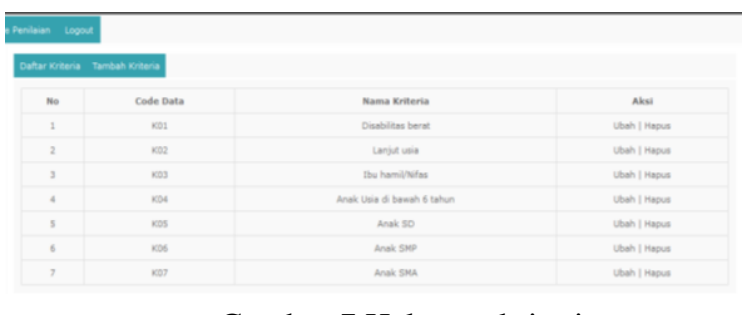

Gambar 7 Halaman kriteria

\section{Halaman Sub Kriteria}

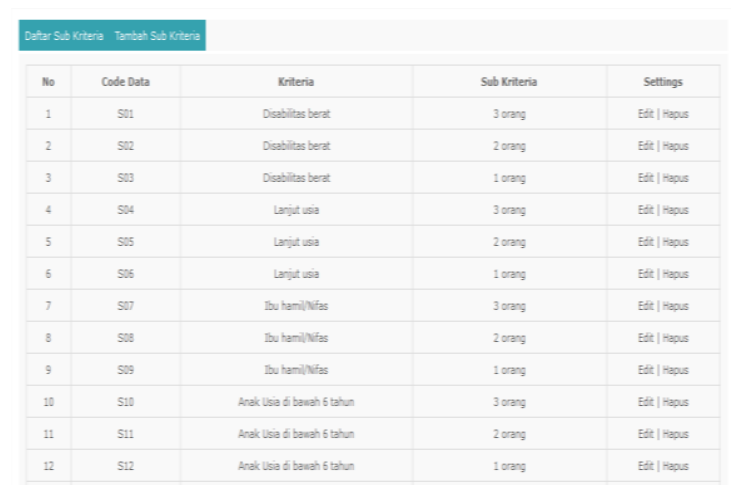

Gambar 8 Halaman sub kriteria

4.4. Implementasi Sistem Pendamping

Berikut adalah halaman utama dari sistem pendukung keputusan pemberian bantuan $\mathrm{PKH}$ di Kota Ternate menggunakan metode AHP. Berikut tampilan halaman utama pendamping dapat dilihat pada gambar 9.

1. Halaman utama pendamping

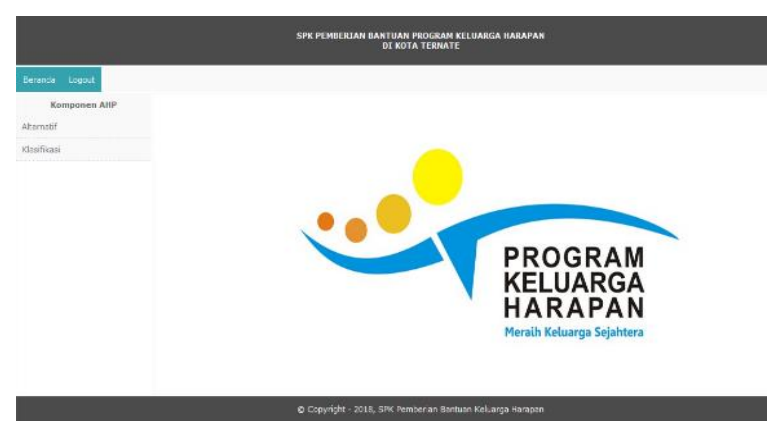

Gambar 9 Halaman utama Pendamping 


\section{Halaman alternatif}

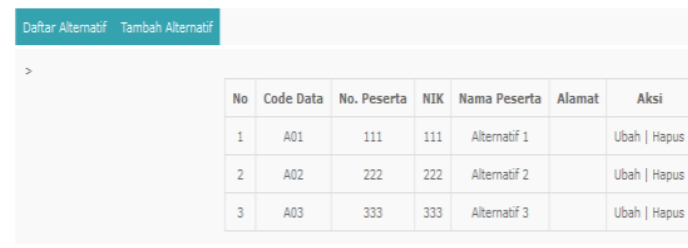

Gambar 10 Halaman alternatif

\section{Halaman Klasifikasi}

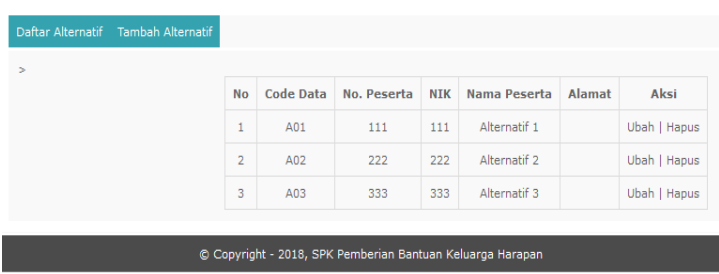

Gambar 11 Halaman klasifikasi

\subsection{Pengujian Perangkat Lunak}

Pada tahap ini dilakukan proses pengujian terhadap suatu sistem yang di bnagun. Pengujian yang akan dilakukan mempunyai mekanisme untuk menemukan data uji yang dapat menguji perangkat lunak secara lengkap dan mempunyai kemungkinan tinggi untuk menemukan kesalahan. Tujuan dari pengujian ini adalah untuk menjamin bahwa perangkat lunak yang dibangun memiliki kualitas yang handal yaitu mampu mempresentasikan kajian pokok dari spesifikasi, analisis, perancangan dan pengkodean dari perangkat lunak itu sendiri. Skenario pengujian pada sistem ini ada lima yaitu pengujian pada halaman login, halaman alternatif, halaman kriteria, halaman sub kriteria, halaman klasifikasi, halaman perbandingan kriteria, Pengujian yang akan dilakukan pada sistem ini yaitu dengan pengujian Black Box seperti yang terlihat pada tabel 4.1 dan tampilan pengujian pada gambar 12 dan gambar 13 .

Tabel 4.1 Pengujian halaman login

\begin{tabular}{|c|c|c|c|}
\hline \multicolumn{4}{|c|}{$\begin{array}{c}\text { Kasus dan Hasil Uji Coba (data yang } \\
\text { dimasukkan benar) }\end{array}$} \\
\hline $\begin{array}{c}\text { Data } \\
\text { Masuk } \\
\text { an }\end{array}$ & $\begin{array}{c}\text { Yang } \\
\text { diharapkan }\end{array}$ & Pengamatan & $\begin{array}{c}\text { Kesimpu } \\
\text { lan }\end{array}$ \\
\hline $\begin{array}{l}\text { Userna } \\
\text { me: } \\
\text { admin } \\
\text { passwo } \\
\text { rd: } \\
\text { admin }\end{array}$ & $\begin{array}{l}\text { Ketika admin } \\
\text { memilih } \\
\text { tombol login } \\
\text { sistem dapat } \\
\text { masuk ke } \\
\text { halaman } \\
\text { menu utama }\end{array}$ & $\begin{array}{l}\text { Dapat masuk } \\
\text { ke menu } \\
\text { halaman } \\
\text { utama }\end{array}$ & Diterima \\
\hline \multicolumn{4}{|c|}{$\begin{array}{l}\text { Kasus dan Hasil Uji (data yang dimasukkan } \\
\text { salah) }\end{array}$} \\
\hline $\begin{array}{c}\text { Data } \\
\text { Masuk } \\
\text { an }\end{array}$ & $\begin{array}{c}\text { Yang } \\
\text { diharapkan }\end{array}$ & Pengamatan & $\begin{array}{l}\text { Kesimpu } \\
\quad \text { lan }\end{array}$ \\
\hline
\end{tabular}

\begin{tabular}{|l|l|l|l|}
\hline Userna & Ketika admin & Tidak dapat & Diterima \\
me: & memilih & masuk menu & \\
admin & tombol login, & pada & \\
1 & sitem tidak & halaman & \\
Passw & akan & utama admin & \\
ord: & menampilkan & & \\
admin & halaman & & \\
1 & utama & & \\
\hline
\end{tabular}

4.6. Analisis

Pada tahapan analisis ini membahas tentang hasil perancangan Sistem Pendukung Keputusan pemberian bantuan PKH pada orang miskin di Kota Ternate. Dimana sistem yang dibangun dari tahapan perancangan menggunakan use case diagram, activity diagram, sequence diagram dapat berjalan sesuai dengan fungsi dari menu yang ada di dalam sistem. Terdapat dua tampilan di dalam sistem yang dibangun yaitu halaman admin dan halaman pendamping. Halaman admin terdiri dari beberapa menu yaitu menu alternatif, klasifikasi, skala penilaian, kriteria, sub kriteria, perhitungan AHP, skor penilaian, management admin, logout, sedangkan halaman pendamping hanya memiliki menu alternatif, klasifikasi dan logout.

Setelah tahapan perancangan, lanjut ke tahapan implementasi sistem. Setelah melewati tahapan pengujian fungsi sistem menggunakan Black Box Testing dan pengujian metode dengan membandingkan perhitungan pada sistem dan perhitungan secara manual yang dilakukan tahapan implementasi sistem sudah berjalan sesuai dengan perancangan yang dibangun, dimana tiap-tiap menu dalam sistem sudah bisa di akses dan digunakan sesuai fungsi dari tiap-tiap menu tersebut.

\section{PENUTUP}

\subsection{Kesimpulan}

Berdasarkan penelitian yang dilakukan dan telah dibahas pada bab-bab sebelumnya, maka dapat diambil kesimpulan sebagai berikut :

1. Sistem Pendukung Keputusan pemberian bantuan PKH di Kota Ternate dibangun dengan tahapan-tahapan mulai dari perancangan sistem, implementasi sistem, sampai pengujian sistem. Dimulai dari perancangan gambar yang digambarkan menggunakan use case diagram, activity diagram, sequence diagram, class diagram dan flowchart, pseudo code, dimana masing-masing diagram membahas secara detail keseluruhan dari sistem, bagaimana admin ataupun pendamping mengoperasikan sistem yang dibangun, gambaran tentang aktivitas yang terjadi di dalam sistem, apa saja yang bisa dilakukan oleh admin dan pendamping didalam sistem.

2. Dari hasil perancangan dan pembuatan sistem ini bahwa pengujian metode berdasarkan perhitungan manual dan perhitungan yang dilakukan oleh sistem terbukti sama dan sesuai dengan yang diharapkan. 


\subsection{Saran}

Adapun saran dari penulis yaitu untuk penelitian sejenis yang akan datang disarankan agar menggunakan metode perhitungan yang berbeda untuk membandingkan hasilnya karena semua metode memiliki kelebihan dan kekurangannya masingmasing.

\section{DAFTAR PUSTAKA}

[1]. Badan Pusat Statistik, Katalog BPS :3205005.82, 2015. Profil Kemiskinan Provinsi Maluku Utara, (http://malut.bps.go.id.) (di akses 14 November 2017 pukul 03.18 PM

[2]. Adisty Sukma Saputri, 2013. Sistem Pendukung Keputusan Pengajuan Dana Kredit Pada PD.BPR Kota Sukabumi Dengan Menggunakan Metode Analytic Hierarchy Process.http://elib.unikom.ac.id/gdl.php?mod=br owse\&op=read\&id=jbptunikompp-gdladistysukm$31637 \& q=$ sistem\%20pendukung\%20keputusan.

[3]. Rifan Syaiful, 2011. Mengenal Metode AHP (Disertai studi kasus Pemilihan Mahasiswa Terbaik) . http://sir.stikom.edu/ahp/1004/.

[4]. Sri Kusumadewi, dkk. 2006. Fuzzy MultiAttribute Decision Making (FUZZY MAMD). Yogyakarta: Graha Ilmu.

[5]. Eni Irviani, 2018. Algoritma K-Means Clustering untuk Menentukan Nilai Gizi Balita. Universitas Bima Sarana Informatika.

[6]. Atikah Arma, 2013. Aplikasi Pembelajaran Mengenal Angka, Bentuk dan Warna untuk Usia 4-5 Tahun Berbasis Android. http://elib.unikom.ac.id/gdl.php?mod=browse\&o $\mathrm{p}=\quad$ read\&id=jbptunikompp-gdl-atikaharma$32072 \& q=a t i k a h$.

[7]. Dinas Sosial (DINSOS) Kota Ternate, 2017. Program Keluarga Harapan Kota Ternate 